\title{
A Single Histidine Residue Is Essential for Zinc Inhibition of GABA p1 Receptors
}

\author{
Tian-Li Wang, ${ }^{1,3}$ Abigail Hackam, ${ }^{3}$ William B. Guggino, ${ }^{1}$ and Garry R. Cutting ${ }^{2,3}$ \\ Departments of ${ }^{1}$ Physiology and ${ }^{2}$ Pediatrics and ${ }^{3}$ Center for Medical Genetics, The Johns Hopkins University \\ School of Medicine, Baltimore, Maryland 21205
}

The GABA $\rho 1$ subunit, cloned from a human retina library, can form homooligomeric receptors with properties similar to $\mathrm{GABA}_{c}$ receptors characterized in retinal cells. The divalent cation $\mathrm{Zn}^{2+}$, abundant in the CNS and retina, was found to inhibit GABA $\rho 1$ receptors in a voltage-independent manner. Varying the extracellular pH from 7.4 to 5.6 significantly reduced this inhibitory effect. This $\mathrm{pH}$ profile suggested that one or more histidine residues might play a role in the interaction between $\mathrm{Zn}^{2+}$ and the GABA $\rho 1$ receptor. Site-directed mutagenesis revealed that a single histidine residue (His 156) in the putative extracellular domain of $\rho 1$ was critical for $\mathrm{Zn}^{2+}$ sensitivity. Substitution of this amino acid with tyrosine (H156Y) created a functional GABA receptor with agonist and channel properties indistinguishable from wildtype. However, the H156Y mutant was insensitive to $\mathrm{Zn}^{2+}$, even at concentrations as high as $1 \mathrm{~mm}$. Mutation to aspartic acid, an amino acid that can interact with $\mathrm{Zn}^{2+}$ in other proteins, preserved sensitivity to $\mathrm{Zn}^{2+}$ but abolished the pH-dependent effect. This histidine residue is also involved in $\mathrm{Ni}^{2+}$ and $\mathrm{Cd}^{2+}$ interaction since the H156Y mutation completely suppressed the inhibition effects of these two cations. These data demonstrate that an extracellular histidine residue is critical for transition metal cation sensitivity of GABA $\rho 1$ receptors.

[Key words: retina, transition metal cations, $\mathrm{pH}$ dependence, voltage independence, site-directed mutagenesis, Xenopus oocyte expression]

The transition metal $\mathrm{Zn}^{2+}$ is abundant in many regions of the brain, most notably the mossy fiber system of the hippocampus (Haug, 1967) and in several ocular tissues, particularly the outer retina (Hirayama, 1990; Wu et al., 1993). One of the proposed functions of $\mathrm{Zn}^{2+}$ in the CNS is to modulate pre- and/or postsynaptic ion channels including $\mathrm{GABA}_{\mathrm{A}}$ and glutamate receptors, voltage-gated $\mathrm{Na}^{+}$channels and $\mathrm{K}^{+}$channels (Legendre and Westbrook, 1990; Harrison and Gibbons, 1994). The mechanism of $\mathrm{Zn}^{2+}$ antagonism of $\mathrm{GABA}_{\mathrm{A}}$ receptors has been suggested by electrophysiological studies of native and recombinant receptors. Whole-cell patchclamp recordings of isolated neuronal cells revealed that the inhi-

\footnotetext{
Received June 12, 1995; revised July 17, 1995; accepted July 25, 1995.

We thank Drs. William Agnew and Peter Maloney for valuable comments and Drs. Richard Huganir and Jeremy Berg for critical reading of this manuscript. This work was supported by NIH Grants HL 47122 (W.B.G.) and EY 09531 (G.R.C.).

Correspondence should be addressed to Garry R. Cutting, M.D., Center for Medical Genetics, Johns Hopkins University, School of Medicine, CMSC 1004 , 600 North Wolfe Street, Baltimore, MD 21287

Copyright $(1995$ Society for Neuroscience $0270-6474 / 95 / 157684-08 \$ 05.00 / 0$
}

bition of $\mathrm{Zn}^{2+}$ is reversible and the blocking effect is noncompetitive and voltage independent (Westbrook and Mayer, 1987; Legendre and Westbrook, 1990). Furthermore, GABA ${ }_{\mathrm{A}}$ receptors in spinal neurons can be inhibited by extracellular $\mathrm{Zn}^{2+}$ but not by $\mathrm{Zn}^{2+}$ that is injected intracellularly (Celentano et al., 1991). These results indicate that $\mathrm{Zn}^{2+}$ does not physically access the channel pore but interacts with residues in the extracellular domain of the $\mathrm{GABA}_{\mathrm{A}}$ receptors. These residues appear to be distinct from those that form the recognition sites for GABA, benzodiazepines, barbiturates, picrotoxin, and steroids (Legendre and Westbrook, 1990; Celentano et al., 1991; Smart, 1992). Studies of recombinant vertebrate $\mathrm{GABA}_{\mathrm{A}}$ receptors demonstrate that sensitivity to $\mathrm{Zn}^{2+}$ is dependent upon subunit composition. Receptors composed of $\alpha$ and $\beta$ subunits are sensitive to $\mathrm{Zn}^{2+}$ whereas inclusion of $\gamma$ subunits creates GABA receptors that are insensitive to $\mathrm{Zn}^{2+}$ (Draguhn et al., 1990; Smart et al., 1991). This situation appears to be more complex, since coexpression with $\delta$ subunits or variation in the $\alpha$ subunit type ( $\alpha 1$ vs $\alpha 2$ or $\alpha 3$ ) moderate the $\mathrm{Zn}^{2+}$ insensitivity of receptors containing $\gamma$ subunits (Saxena and Macdonald, 1994; White and Gurley, 1995).

A novel class of GABA receptor called type $C$ has been identified in retina (Feigenspan et al., 1993; Qian and Dowling, 1993). These receptors exhibit a number of characteristics that distinguish them from $\mathrm{GABA}_{\mathrm{A}}$ receptors including a lack of sensitivity to bicuculline, barbiturates, and benzodiazepines. Many of these distinct properties are shared by GABA receptors formed of $\rho$ subunits (Shimada et al., 1992; Wang et al., 1994). These subunits were identified in retina raising the possibility that retinal $\mathrm{GABA}_{\mathrm{C}}$ receptors are formed partially or wholly of $\rho$ subunits. $\mathrm{GABA}_{\mathrm{C}}$ reccptors are present in cell types in regions of the retina with high $\mathrm{Zn}^{2+}$ concentrations, and it appears that $7 \mathbf{n}^{2+}$ acts as a mixed antagonist for this class of GABA receptor (Dong and Werblin, 1995). Likewise, GABA-gated chloride currents generated by homooligomeric $\rho 1$ and $\rho 2$ receptors expressed in Xenopus oocytes are irrhibited by $\mathrm{Zn}^{2+}$, and $\mathrm{Zn}^{2+}$ inhibition of GABA $\rho 1$ receptors displays competitive and noncompetitive components (Calvo et al., 1994; Wang et al., 1994; Chang et al., 1995). We report that a single residue in the putative extracellular domain is critical for sensitivity of $\rho 1$ receptors to $\mathrm{Zn}^{2+}$ and two other transition metal cations, $\mathrm{Ni}^{2}$ and $\mathrm{Cd}^{2+}$. This study establishes a molecular basis for $\mathrm{Zn}^{2+}$ modulation of $\mathrm{GABA}_{\mathrm{C}}$ receptors in the outer retina.

\section{Materials and Methods}

Chimera construction. A $\rho 2 \rho 1-\mathrm{B}$ chimeric cDNA encoding amino acids 1 to 62 of $\rho 2$ and amino acids 72 to 473 of $\rho 1$ was generated by twostep polymerase chain reaction as previously described (Yon and Fried, 1989). The primers used were: 5'- $\rho 2$ primer: 5'-CGGCGGATCCA- 
CAGGCTACTGGAAAGCAGC-3' $3^{\prime}$ 2 $p 1$-B hybrid primer: 5'-TCCGGAAGGGAAAGCCTCAGCAGCCTTCTGAGGATAGATGAC-3' $3^{\prime}-\rho 1$ primer: 5'-CTGCAGCTTTCCAAAGCT-3'. The final PCR amplification product was subcloned into the PCR II vector (TA cloning kit, Invitrogen). Authenticity of the chimeric construct was confirmed by dideoxynucleotide sequencing of the entire cDNA.

Site-directed mutagenesis and in vitro RNA synthesis. Oligonucleotide-mediated mutagenesis was performed on $\rho 1$ uracil-containing single-strand DNA using the Muta-gene Phagemid in vitro mutagenesis kit (Bio-Rad) or by double-stranded mutagenesis with the Transformer SiteDirected Mutagenesis Kit (Clontech). The sequences of the mutagenic oligos were as follows: H78Y, 5'-CTGA AATCATAGTCATCTATC-3'; H120Q, 5'-CTTCCAGTACTGCCTCAGG-3'; H156C, 5'-GCGTTTGGAGCACACGAAAAACA- $-3^{\prime}$; H156D, 5'-GCGTTTGGAGTCCACGAAAAACA-3'; H156N, 5'-GCGTTTGGAGTTCACGAAAAACA-3'; H156Y, 5'-GCGTTTGGAGTACACGAAAAA $\bar{C}$ A-31; H163N, 5'-GGTGGTGTCGTTGATGAAGGAGC-3'; H163Y, 5'-CTGTGGTGGTGTCGTAGATGAAAGGAGCG-3'; H248Q, $5^{\prime}$-GGTGGTGGTCTGAAATTCCTG-3'; H274Y, 5'-GAAGATGTAGCGCCGCAACG-3'; H4477N, 5'CAATGGCGTTGGTÄTCGATTC-3'.

Mutations were confirmed by dideoxynucleotide sequencing the mutated nucleotide and approximately 100 nucleotides flanking each side of the mutation. Capped cRNA was synthesized in vitro using a Megascript Kit (Ambicon). Both $\rho 1$ and mutant plasmid DNAs were linearized with Bam HI, and cRNA was synthesized from each DNA template using T3 RNA polymerase.

Oocyte preparation and electrophysiology. Oocyte preparation and RNA injection were performed as described previously (Wang et al., 1994). Stage V or VI oocytes isolated from adult female Xenopus (Nasco, Michigan) were injected with either 5 or $10 \mathrm{ng}$ of $\rho 1$ RNA or 5 to $50 \mathrm{ng}$ of mutant RNA in a $50 \mathrm{nl}$ volume by a positive-displacement micropipette (Drummond, PA). In experiments comparing responses of mutant receptors to those of $\rho 1$ receptors, the amount of mutant cRNA injected was adjusted to obtain whole-cell currents that were within $20 \%$ of those generated by $5 \mathrm{ng}$ of $\rho 1 \mathrm{cRNA}$.

Voltage clamp. GABA-induced currents were recorded from individual oocytes using the two-electrode voltage-clamp tcchnique with an Axonclamp-2A amplifier (Axon Instruments, CA) as described previously (Wang et al., 1994). Voltage pulse protocols and data acquisition were performed by a pCLAMP computer software (Version 5.51, Axon Instruments, CA). Two days after RNA injection, oocytes were placed in a $800 \mu$ l recording chamber with bath solution (ND96) continuously perfused by gravity at a flow rate of $300 \mu \mathrm{l} / \mathrm{sec}$. ND96 contains $96 \mathrm{~mm}$ $\mathrm{NaCl}, 2 \mathrm{mM} \mathrm{KCl}, 1 \mathrm{mM} \mathrm{MgCl}, 1 \mathrm{mM} \mathrm{CaCl}$, and $5 \mathrm{mM}$ HEPES ( $\mathrm{mH}$ 7.4). GABA, with or without other drugs, was applied to the oocyte by bath perfusion. The rate of agonist application was suitable for $\rho 1$ receptors since the GABA-induced currents show minimal desensitization as observed by others (Amin and Weiss, 1994; Calvo et al., 1994). The current reached a peak within $2 \mathrm{sec}$, and there was little or no decline in current during 2-3 min of GABA application. Since $\mathrm{Zn}^{2+}$ inhibition of GABA $\rho 1$ receptors is agonist dependent (Calvo et al., 1994; Chang et al., 1995), the same concentration of GABA $(5 \mu \mathrm{M})$ was used in all experiments examining metal cation inhibition. The $\mathrm{pH}$ values of ND96 was adjusted to 5.6, 6.5, and 7.4 using $0.5 \mathrm{~N} \mathrm{NaOH}$. GABA and $\mathrm{ZnCl}_{2}$ were obtained from Sigma, St. Louis, $\mathrm{MO}$, and $\mathrm{NiCl}_{2}$ and $\mathrm{CdCl}_{2}$ were from Aldrich Chemicals, Milwaukee, WI. These chemicals were dissolved in $\mathrm{dd}_{2} \mathrm{O}$ as $1 \mathrm{M}$ stocks then diluted in ND96 to obtain test concentrations. Recording electrodes, filled with $3 \mathrm{M} \mathrm{KCl}$, with resistances of $0.503 \mathrm{M} \Omega$ were used for recordings. The membrane potential was held at $-50 \mathrm{mV}$ continuously unless a current-voltage clamp protocol was performed (Figs. 1, 5). The trial number $(n)$ represents the number of oocytes studied. Each oocyle served as its own pretreatment control. A minimum of three oocytes from at least two frogs were studied per experiment.

Data analysis. In all experiments except Figure 5, the current observed in the presence of drug(s) was subtracted from the current in the absence of any drug (corresponding to background current of the oocyte) by pCLAMP software. Data shown in Figure 5 were the original tracings before and after drug application without any subtraction. The $\mathrm{N}$-fit program (The University of Texas, Galveston) was used to perform curve fitting of dose-dependent relations. The GABA dose-response relation was constructed at a wide range of GABA concentrations. The Hill equation $I(x)=I_{\max } / 1+\left(\mathrm{EC}_{50} /[\mathrm{GABA}]\right)^{n}$ was used to fit the normalized data points; $I_{\max }$ is the maximal current response eliciting by GABA; $E_{50}$ is the concentration of GABA that elicits half-maximal
A I (nA)

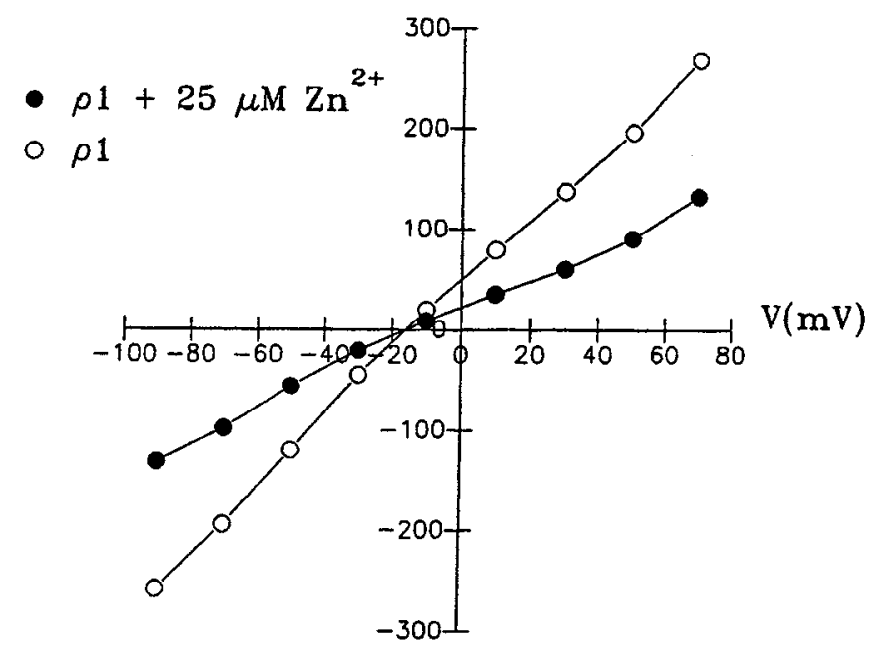

B

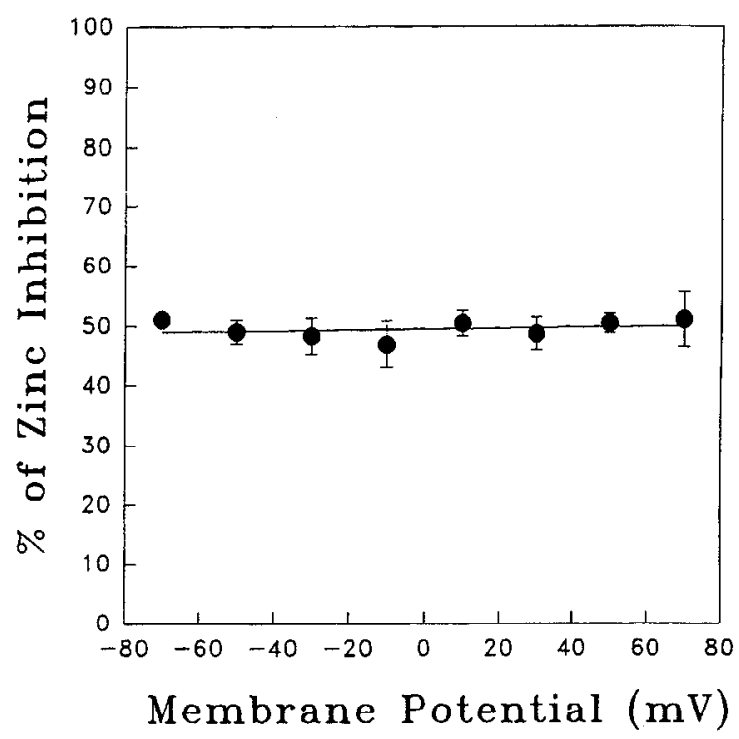

Figure 1. Voltage-independent inhibition of $\mathrm{Zn}^{2+}$ on GABA $\rho 1$ currents. $A$, A representative current-voltage plot of $\rho 1$ GABA-elicited

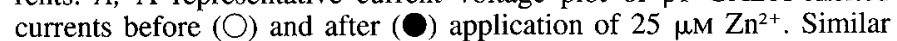
results were observed in four different oocytes. At $+50 \mathrm{mV}, 50.4 \pm$ $1.6 \%$ of current was inhibited $(n=4)$; at $-50 \mathrm{mV}, 49.0 \pm 2.0 \%$ of current was inhibited $(n=4)$. $B$, Fractional blocking effect of $\mathrm{Zn}^{2+}$ at various voltage potentials. The inhibitory effect was measured as the ratio of GABA-induced current in the presence of $\mathrm{Zn}^{2+}$ to that in the absence of $\mathrm{Zn}^{2+}$ at a range of holding potentials (from $-70 \mathrm{mV}$ to 70 $\mathrm{mV}$ with $20 \mathrm{mV}$ increment steps). GABA $(5 \mu \mathrm{M})$ was used to elicit current response and $25 \mu \mathrm{M} \mathrm{Zn}^{2+}$ was applied to inhibit that current. Data are expressed as mean and SEM from four different oocytes. The data points fittcd by lincar regression produced a line that is parallel to the $\bar{X}$-axis.

response $\left(1 / 2 I_{\max }\right) ; n$ represents the Hill coefficient. To quantify the inhibitory effect of antagonist upon GABA-induced currents, the inverse Hill Equation $I(x)=I_{\max } / 1+\left([\text { Antagonist }] / \mathrm{CC}_{50}\right)^{n}$ was used to fit the normalized current response versus antagonist concentration. $\mathrm{IC}_{50}$ represents the concentration of $\mathrm{Zn}^{2+}$ that blocks half-maximal current response; $I_{\max }$ is the maximal current eliciting by GABA in the absence of $\mathrm{Zn}^{2+} ; n$ represents the inverse Hill coefficient. The top of dose- 


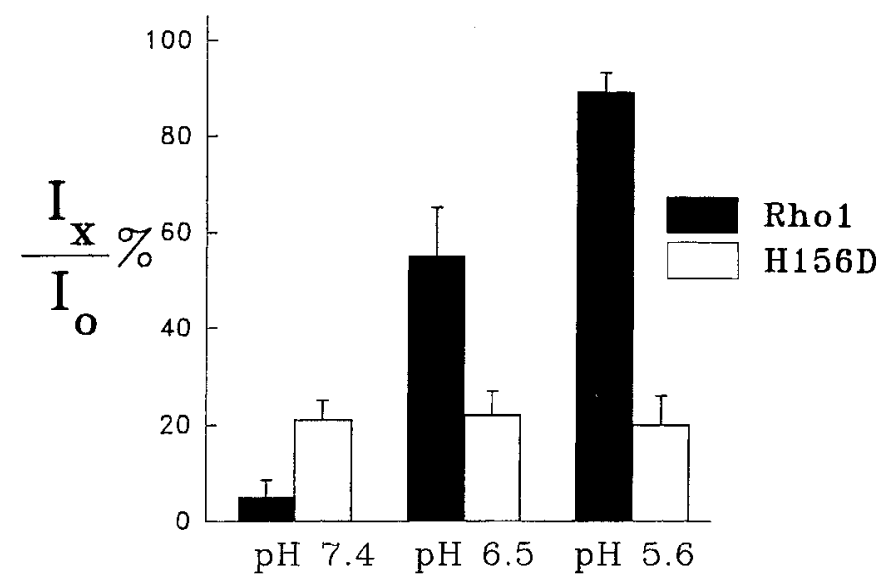

Figure 2. $\mathrm{pH}-$ Dependent $\mathrm{Zn}^{2+}$ inhibition effect on $\rho 1$ and $\mathrm{H} 156 \mathrm{D}$ receptors. GABA-gated currents were measured before or after exposure to $\mathrm{Zn}^{2+}$ at different $\mathrm{pH}$ values. Three different $\mathrm{pH}$ values of perfusion solution were tested: $\mathrm{pH} 5.6, \mathrm{pH} 6.5$, and $\mathrm{pH} 7.4$. The data are normalized as $I_{\mathrm{x}} / I_{\mathrm{O}}$ (percentage). $I_{\mathrm{O}}$ is the current response to $5 \mu \mathrm{M} \mathrm{GABA}$ $I_{X}$ is the current response to $5 \mu \mathrm{M}$ GABA coapplied with $200 \mu \mathrm{M} \mathrm{Zn}{ }^{2+}$ at each $\mathrm{pH}$. Data: mean + SFM. Four oncytes injected with $\rho 1$ and four oocytes injected with H156D were studied at each $\mathrm{pH}$.

response relations were determined when a 500 -fold concentration increase did not change current amplitude by more than $1 \%$. Student's $t$ test was used to determine the statistical significant difference between two sample groups. In this study, independent sampling and comparison were used, and $p<0.01$ was set as a significant level.

\section{Results}

$\mathrm{Zn}^{2+}$ inhibition of GABA $\rho \mathrm{l}$ receptors is voltage independent and $\mathrm{pH}$ dependent

We and others have demonstrated that $\mathrm{Zn}^{2+}$ inhibits GABA $\rho 1$ receptors in a dose-dependent fashion (Calvo et al., 1994; Wang et al., 1994; Chang et al., 1995). Further studies were pcrformed to characterize the blocking effect of $\mathrm{Zn}^{2+}$ upon homooligomeric $\rho 1$ receptors expressed in Xenopus oocytes. $\mathrm{Zn}^{2+}$ inhibited $\rho 1$ receptors over a wide range of membrane potentials without significantly affecting the linearity of the current-voltage relationship (Fig. 1A). The fraction of GABA-gated currents blocked by $25 \mu \mathrm{M}, \mathrm{Zn}^{2+}$ was almost constant at each voltage potential (Fig. $1 B$ ). These observations indicate that $\mathrm{Zn}^{2}$ inhibits GABA $\rho 1$ receptors in a voltage-independent manner. The inhibitory effect of $\mathrm{Zn}^{2+}$ upon some native $\mathrm{GABA}_{\mathrm{A}}$ receptors can be influenced by changes in extracellular pH (Smart and Constanti, 1982). To evaluate this possibility for $\rho 1$ receptors, the $\mathrm{pH}$ of the solution bathing the oocytes was varied from 7.4 to 5.6. Different external $\mathrm{pH}$ conditions did not significantly affect the magnitude of GABA-elicited currents in four oocytes studied (data not shown). However, $\mathrm{Zn}^{2+}$ inhibition of the currents activated by 5 $\mu \mathrm{M}$ GABA decreased as $\mathrm{pH}$ decreased (Fig. 2). At pH 7.4, 200 $\mu \mathrm{M} \mathrm{Zn}^{2+}$ inhibited almost all currents $(92.8 \pm 3.6 \%)$; at $\mathrm{pH} 6.5$, approximately half of the currents were inhibited $(42.4 \pm 8.3 \%)$, and at $\mathrm{pH} 5.6$, about one-tenth of currents $(12.2 \pm 4.0 \%)$ were inhibited. These data demonstrate that decreasing extracellular $\mathrm{pH}$ affects $\mathrm{Zn}^{2+}$ interaction with $\rho 1$ receptors.

\section{A histidine residue in the putative amino terminal domain of $\rho 1$ confers sensitivity to $\mathrm{Zn}^{2+}$}

The $\mathrm{pH}$ dependency of the $\mathrm{Zn}^{2+}$ inhibition suggested that one or more histidine residues may play a critical role in the sensitivity of $p 1$ receptors to this cation. Inspection of the predicted

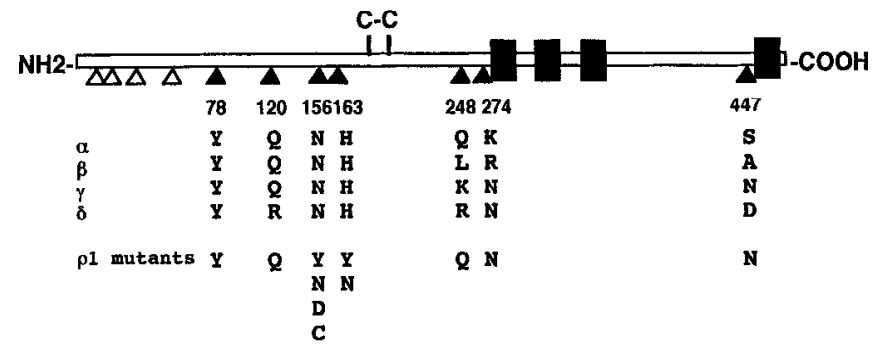

Figure 3. Schematic representation of the relative locations of the histidine residues of the GABA $\rho 1$ subunit and the mutants used in this study. Amino acis are in single letter code. $C$-C indicates the location of a pair of highly conserved cysteine residues and filled boxes represent hydrophobic membrane-spanning segments M1 to M4. Numbers refer to the codons of the predicted amino acid sequence of the full-length cDNA (canonical methionine being codon 1) (Cutting et al., 1991). Histidines conserved between $\rho 1$ and $\rho 2$ subunits are indicated by filled triangles and four nonconserved histidines are shown by open triangles. Amino acids in human $\alpha 1$, human $\beta 1$, human $\alpha 2$, and rat $\delta$ subunits in the same location as each filled triangle are shown in single letter code (Cutting et al., 1991).

amino acid sequence of $\rho 1$ revealed eleven histidine residues. Ten are located in the putative extracellular N-terminal domain and one immediately precedes the fourth hydrophobic segment (Fig. 3). Seven of these histidine residues are conserved between $\rho \mathrm{l}$ and the $\mathrm{Zn}^{2+}$-sensitive $\rho 2$ subunit (Fig. 3). To determine whether any of the four nonconserved histidines near the $\mathrm{N}$-terminus of $\rho 1$ influenced $\mathrm{Zn}^{2+}$ sensitivity, a chimera exchanging the $N$-terminal regions of $\rho 1$ and $\rho 2$ was created $(\rho 2 \rho 1-B)$ that retained the seven conserved histidines. This chimera generated robust currents in oocytes that, like $\rho 1$, were sensitive to $\mathrm{Zn}^{2+}$ (Fig. 4A). The remaining seven histidines were then mutated individually and the resulting mutant was tested for sensitivity

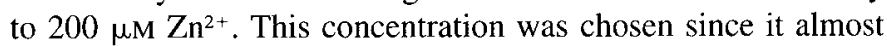
completely inhibits $\rho 1$ currents elicited by $5 \mu \mathrm{M}$ GABA. The choice of the amino acid selected to substitute for histidine was based on the residues most frequently found at the same location in $\mathrm{GABA}_{\mathrm{A}}$ subunits (Fig. 3). Five histidine mutants (H78Y, H120Q, H248Q, H274N, and H447N) generated robust GABAgated chloride currents that were sensitive to $\mathrm{Zn}^{2+}$ (Fig. 4A). The amino acid substituted for histidine in each case (asparagine, glutamine, or tyrosine) has not been shown to donate electrons to $\mathrm{Zn}^{2+}$ (Coleman, 1992). These results eliminated these five histidines as significantly contributing to the interaction between $\rho 1$ receptors and $\mathrm{Zn}^{2+}$.

Substitution of the histidine at codon 163 with either asparagine or tyrosine prevented the formation of functional GABAgated receptors. GABA concentration was increased to $1 \mathrm{mM}$ without response $(n=8)$. This result was not unexpected since this histidine is completely conserved among $\mathrm{GABA}_{\mathrm{A}}$ and $\rho$ subunits, suggesting that it is critical for function. Mutation of the histidine residue at codon 156 to asparagine $(\mathrm{H} 156 \mathrm{~N})$, the residue found in the corresponding location of all $\mathrm{GABA}_{\Lambda}$ subunits, produced a mutant that did not respond to $\mathrm{GABA}$ up to $1 \mathrm{mM}$ $(n=4)$. To eliminate the possibility that a second mutation had been inadvertently introduced elsewhere in the cDNA during mutagenesis, three independent $H 156 \mathrm{~N}$ clones were studied. None of the mulants produced a functional GABA receptor. However, substitution with tyrosine $(\mathrm{H} 156 \mathrm{Y})$ resulted in functional channels that were insensitive to $\mathrm{Zn}^{2+}$, even at concentrations as high as $1 \mathrm{~mm}$ (Fig. $4 B$ ). Two mutants were created in which the histidine at codon 156 was replaced with amino acids 

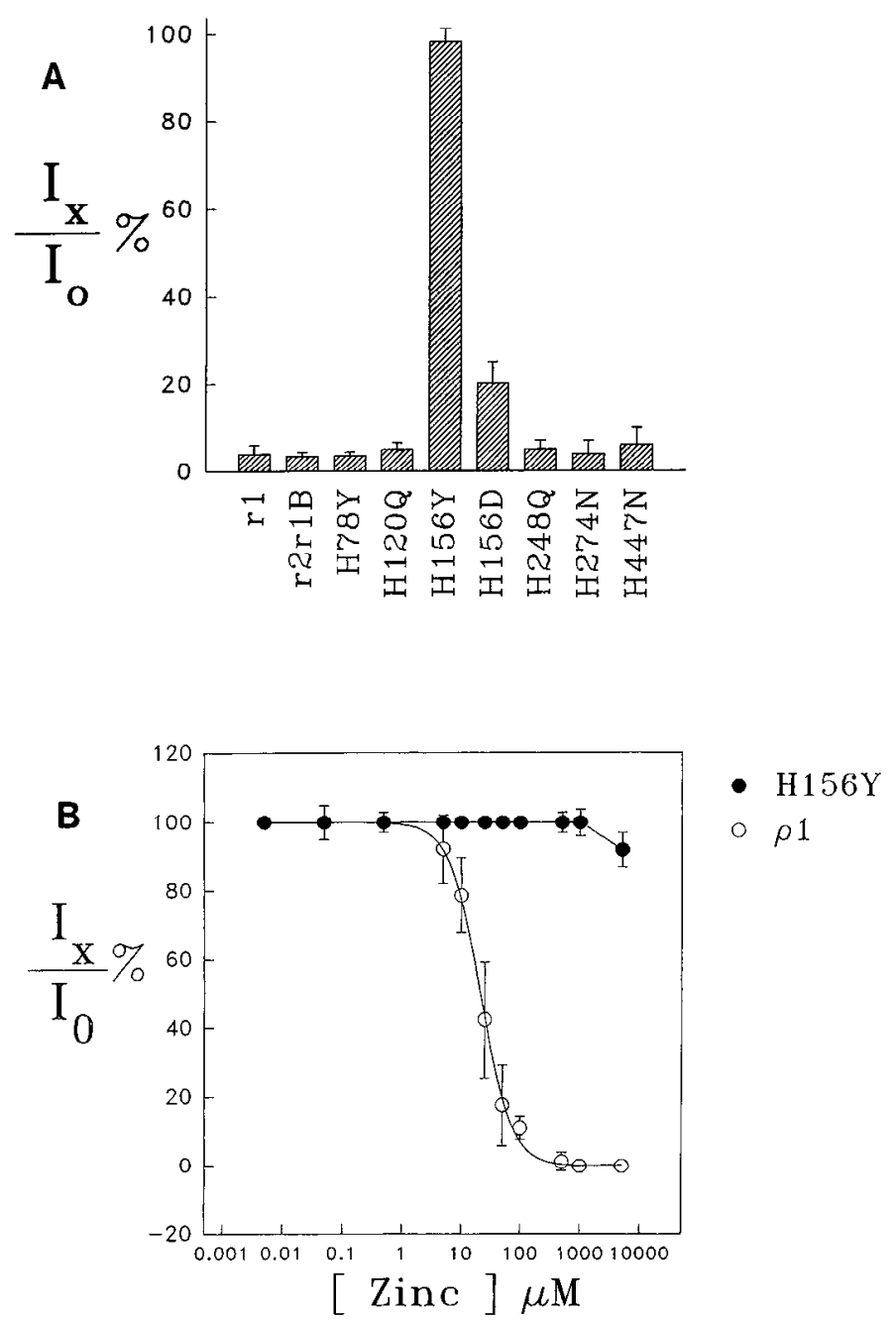

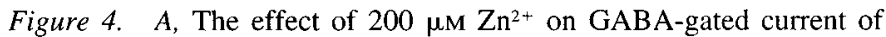
homooligomeric $\rho 1(\mathrm{r} 1), \rho 2 \rho 1-\mathrm{B}(\mathrm{r} 2 \mathrm{r} 1 \mathrm{~B})$ and $\rho 1$ mutants. $B$, Inhibition effects of a wide range of $\mathrm{Zn}^{2+}$ concentration upon GABA-gated currents of $\rho 1$ and the $\mathrm{H} 156 \mathrm{Y}$ mutant. The $\mathrm{Y}$-axis for both $A$ and $B$ are the normalized response, $I_{\mathrm{X}} / I_{\mathrm{O}} \% . I_{\mathrm{O}}$ is the current response to $5 \mu \mathrm{M}$ GABA and $I_{\mathrm{X}}$ is the current response to $\mathrm{Zn}^{2+}$ coapplied with $5 \mu \mathrm{M}$ GABA. Data are presented as mean and SEM. $n=5$ for each group in $A ; n=3$ for each group in $B$.

that can interact with $7 \mathrm{n}^{2+}$ : cysteine $(\mathrm{H} 156 \mathrm{C})$ and aspartic acid (H156D). Although the H156C mutant failed to produce currents, $\mathrm{H} 156 \mathrm{D}$ generated a GABA-gated conductance that was sensitive to $\mathrm{Zn}^{2+}$ (Fig. 4). Unlike $\rho \mathrm{l}$, however, $\mathrm{Zn}^{2+}$ inhibition of the H156D mutant was not affected by changes in extracellular pH (Fig. 2). Therefore, the nature of the residue at codon 156 is critical for $\mathrm{Zn}^{2+}$ sensitivity of $\rho 1$ receptors.

Histidine at codon 156 is also critical for $\mathrm{Ni}^{2+}$ and $\mathrm{Cd}^{2+}$ inhibition of $\rho 1$ receptors

A number of transition metal cations including $\mathrm{Cd}^{2+}$ and $\mathrm{Ni}^{2+}$ can inhibit $\mathrm{GABA}_{\mathrm{A}}$ receptors (Akimichi and Tachibana, 1986; Smart and Constanti, 1990; Celentano et al., 1991). Both cations also inhibit $\rho 1$ currents (Calvo et al., 1994); the potency of $\mathrm{Ni}^{2+}$ inhibition was similar to that of $\mathrm{Zn}^{2+}$, whereas $\mathrm{Cd}^{2+}$ was considerably weaker. The linearity of the current-voltage relationship was not affected by $\mathrm{Ni}^{2+}$ or $\mathrm{Cd}^{2+}$, indicating that the blocking mechanism of these cations, like $\mathrm{Zn}^{2+}$, was voltage independent (Fig. 5). To determine if these divalent cations share with
$\mathrm{Zn}^{2+}$ the same site of interaction, the blocking efficiency of $\mathrm{Ni}^{2+}$ and $\mathrm{Cd}^{2+}$ upon the $\mathrm{H} 156 \mathrm{Y}$ mutant was examined. At $250 \mu \mathrm{M}$ of $\mathrm{Ni}^{2+}$ (Fig. 5A) and $500 \mu \mathrm{M}$ of $\mathrm{Cd}^{2+}$ (Fig. 5B), $\mathrm{\rho l}$ currents were almost completely eliminated, whereas $\mathrm{H} 156 \mathrm{Y}$ currents were unaffected by the two cations at these concentrations. Like $\mathrm{Zn}^{2+}$, $\mathrm{Ni}^{2+}$ and $\mathrm{Cd}^{2+}$ could not inhibit the chloride currents of the H156Y mutant receptors even at concentrations as high as $1 \mathrm{~mm}$.

Mutation of the histidine residue at position 156 of $\rho 1$ appears specific for divalent cation sensitivity

To determine whether the $\mathrm{H} 156 \mathrm{Y}$ mutation had more pervasive effects upon receptor function, the agonist binding affinity and channel properties were studied in detail and compared to receptors formed by wild-type $\rho 1$. Similar to $\rho 1$, the H156Y mutant expressed robustly GABA-gated whole-cell currents ranging from 200 to $800 \mathrm{nA}$, depending on the batch of oocytes injected. The $\mathrm{H} 156 \mathrm{Y}$ receptors had a linear current-voltage relationship (Fig. 5) and a chloride-selective reversal potential (Table 1). Its affinity to $\mathrm{GABA}\left(\mathrm{EC}_{50}=2.1 \mu \mathrm{M} \pm 0.3 ; n=3\right)$ did not differ significantly from that of $\rho 1$ (Table 1). The H156Y mutant is antagonized by picrotoxin with an $\mathrm{IC}_{5,1}$ of $34.1 \pm 6.0 \mu \mathrm{M}(n=$ 3 ) that is not significantly different from the value of $\rho 1$ receptors (Table 1). These data suggested that $\mathrm{Zn}^{2+}$ sensitivity is conferred by a different region of $\rho$ l subunits than those involved with agonist binding, anion conduction, or picrotoxin interaction.

Increasing the ratio of coinjected $H 156 Y$ to $\rho$ l $c R N A$ progressively decreases the $\mathrm{Zn}^{2+}$ sensitivity of GABA-gated currents

It has been suggested that presence of $\gamma$ subunits confers $\mathrm{Zn}^{2+}$ insensitivity to heterooligomeric $\mathrm{GABA}_{\mathrm{A}}$ receptors (Draguhn et al., 1990; Smart et al., 1991). To determine if the $\mathrm{Zn}^{21}$ insensitive $\mathrm{H} 156 \mathrm{Y}$ mutant had the same effect upon $\rho 1$ receptors, Xenopus oocytes were injected with a constant amount of $\rho 1$ cRNA and increasing amounts of H156Y mutant cRNA. As shown in Figure 6, oocytes injected with both cRNAs generated GABAgated currents with $\mathrm{Zn}^{2+}$ sensitivity profiles that were distinct from those generated by $\rho 1$ or by $\mathrm{H} 156 \mathrm{Y}$ alone. Increasing amounts of $\mathrm{H} 156 \mathrm{Y}$ mutant cRNA generated currents that rapidly became insensitive to $\mathrm{Zn}^{2+}$ inhibition. For example, $100 \mu \mathrm{M}$ and

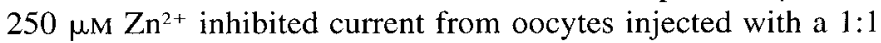
ratio of $\rho 1$ to $\mathrm{H} 156 \mathrm{Y}$, but not as potently as oocytes injected with $\rho 1$ alone. When a $1: 2$ ratio of $\rho 1$ to $H 156 Y$ cRNA was injected, currents elicited by GABA were much less sensitive to

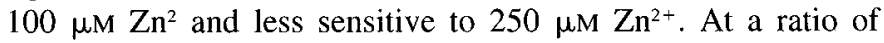
$1: 4$, even though $20 \%$ of the injected cRNA was $\rho 1$, the GABAgated currents were virtually insensitive to $\mathrm{Zn}^{2}$. These data suggest that coexpression of the $\mathrm{H} 156 \mathrm{Y}$ mutant does affect the $\mathrm{Zn}^{2+}$ sensitivity of $\rho 1$ receptors.

\section{Discussion}

In this study, the mechanism of $\mathrm{Zn}^{2+}$ inhibition of homooligomeric GABA $\rho 1$ receptors was investigated at the molecular level. The inhibitory effect of this cation was voltage independent and attenuated by decreasing the $\mathrm{pH}$ of the bath solution. These results suggested an extracellular site of interaction distinct from the ion channel of the receptor. The $\mathrm{pH}$ dependency of the $\mathrm{Zn}^{2+}$ inhibitory effect raised the possibility that $\mathrm{H}^{+}$was interfering with the binding of this cation to an inhibitory motif. Studies of $\mathrm{Zn}^{2+}$-interacting proteins have shown that this cation can be coordinated to four Cys residues or three amino acids, 


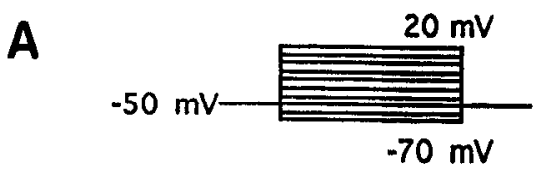

Rho1

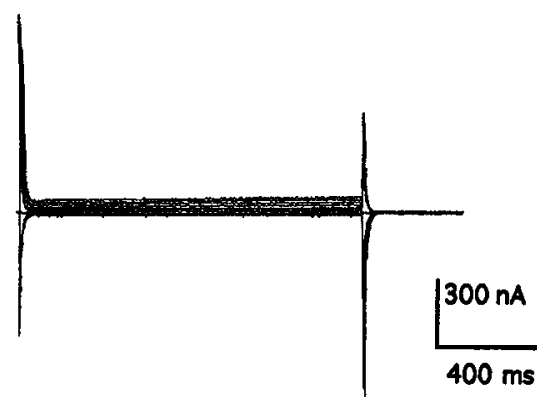

H156Y

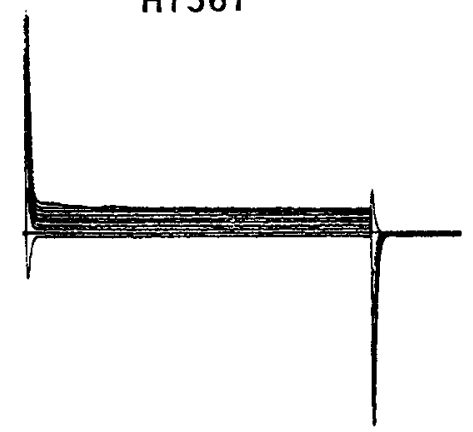

Rho1

$5 \mu M$ GABA

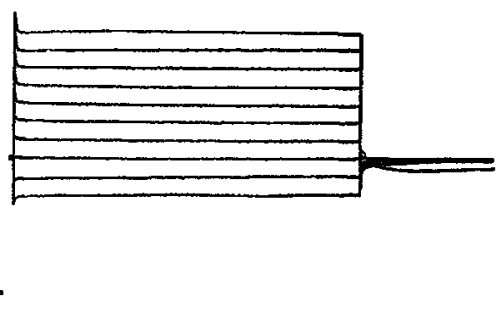

H156Y

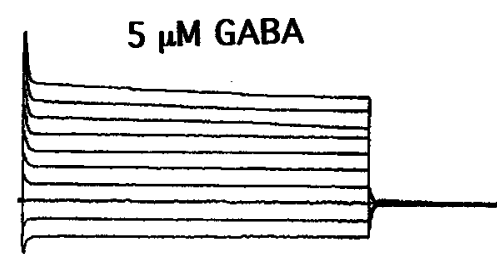

$\frac{L^{200 \mathrm{nA}}}{400 \mathrm{~ms}}$
Rho1

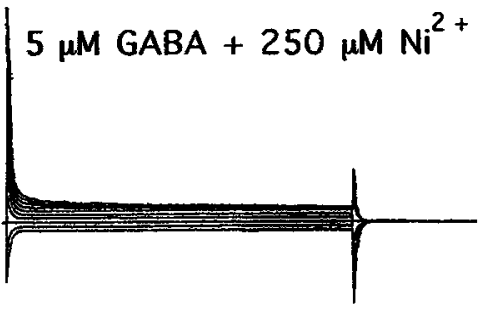

H156Y

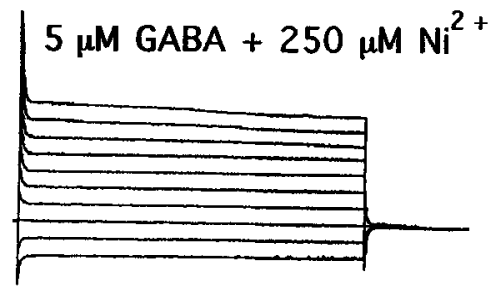

Figure 5. Inhibition effects of $\mathrm{Ni}^{2+}$ and $\mathrm{Cd}^{2+}$ on $\rho 1$ and $\mathrm{H} 156 \mathrm{Y}$ currents. In both $A$ and $B$, the current tracings were recorded with a experimental protocol that held the membrane potential at $-50 \mathrm{mV}$ and stepped from $-70 \mathrm{mV}$ to $20 \mathrm{mV}$ by $10 \mathrm{mV}$ increments. $A$, Inhibition of $\rho 1$ and $\mathrm{H} 156 \mathrm{Y}$ currents by $250 \mu \mathrm{M} \mathrm{Ni}{ }^{2+}$. The tracings shown at the left-hand side are the intrinsic currents of the oocyte; the tracings in the middle are currents elicited by $5 \mu \mathrm{M}$ GABA, and the tracings shown on the right are the responses of the same oocyte upon $250 \mu \mathrm{M} \mathrm{Ni}^{2+}$ and $5 \mu \mathrm{M}$ GABA coapplication.

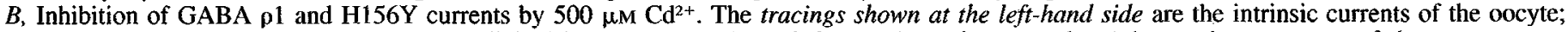
the tracings at the middle are the currents elicited by $5 \mu \mathrm{M} \mathrm{GABA}$; and the tracings shown at the right are the responses of the same oocyte stimulated by $500 \mu \mathrm{M} \mathrm{Cd}{ }^{2+}$ and $5 \mu \mathrm{M}$ GABA coapplication. Similar recordings were obtained from five oocytes for each group.

usually a combination of Cys, His, Glu, and/or Asp residues, and an activated water molecule (Vallee and Auld, 1990; Coleman, 1992). Of the four amino acids, histidine has a titratable $\mathbf{R}$ group in solution in the $\mathrm{pH}$ range used in this study. We therefore speculated that $\mathrm{Zn}^{2+}$ may be interacting with a histidine residue that had a similar $\mathrm{pK}_{\mathrm{R}}$ value in the protein as in solution. Site-directed mutagenesis of each histidine residue revealed that substitution of a single amino acid (His156) in the putative extracellular domain of $\rho 1$ significantly altered $\mathrm{Zn}^{2+}$ sensitivity of $\rho 1$ receptors. The almost complete elimination of the inhibitory effect of $\mathrm{Zn}^{2+}$ by this mutation indicates that $\mathrm{Zn}^{2+}$ inhibition of GABA-gated currents occurs by interaction with the GABA receptor as opposed to channel blockade or complexing with GABA or chloride ions.

$\mathrm{X}$-ray crystallographic studies of $\mathrm{Zn}^{2+}$-containing metalloenzymes indicate that the imidazole group of histidine can interact directly with $\mathrm{Zn}^{2+}$ (Vallee and Auld, 1990). Thus, His156 may form part of a $\mathrm{Zn}^{2+}$ binding pocket involving one or more other amino acids in the subunit. Alternatively, substitution of His 156 with tyrosine may cause local changes in conformation that allosterically alter the interaction of $\mathbf{Z n}^{2+}$ with amino acids distinct from His156. The loss of function caused by the substitution of
His 156 with asparagine or cysteine supports this concept. However, the structural change would have to be quite discrete since responses to GABA and to picrotoxin and channel properties of H156Y receptors were indistinguishable from those of wild-type receptors (Table 1). Experiments involving the H156D mutant appear to provide the most convincing argument that His156 is directly involved in $\mathrm{Zn}^{2+}$ binding. Histidine to aspartic acid is a nonconservative substitution, yet robust currents were generated upon application of GABA, and $\mathrm{Zn}^{2+}$ sensitivity was retained. An important observation was the loss of the $\mathrm{pH}$ effect upon $\mathrm{Zn}^{2+}$ inhibition over the range uscd in the study (7.4 to 5.6). We propose that the aspartic acid residue coordinates with $\mathrm{Zn}^{2+}$, but $\mathrm{H}^{+}$ions do not interfere with this interaction because of the low $\mathrm{pK}_{\mathrm{R}}$ (3.86 in solution) of this amino acid. These data suggest that the nature of the amino acid at codon 156 plays a critical role in conferring $\mathrm{Zn}^{2+}$ sensitivity to the GABA $p 1$ receptor.

The proximity of a histidine at codon 163 and two cysteine residues to His 156 raises the possibility of a $\mathrm{Zn}^{2+}$ binding motif similar to that observed in transcription factors containing $\mathrm{Zn}^{2+}-$ fingers (Fig. 3). However, the latter structure is formed by two Cys residues preceding two His residues with relatively specific distances between each amino acid (Jacobs, 1995). In addition, 


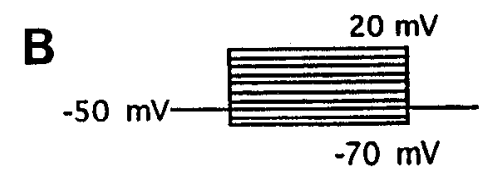

Rho1

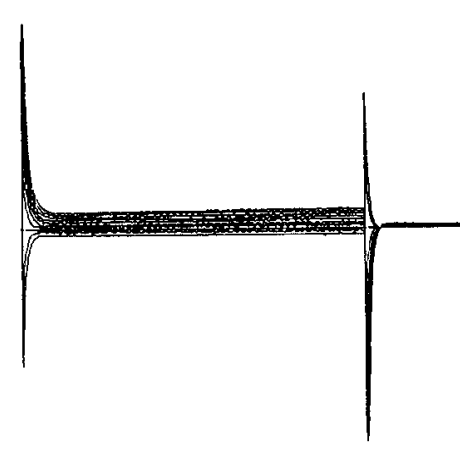

H156Y

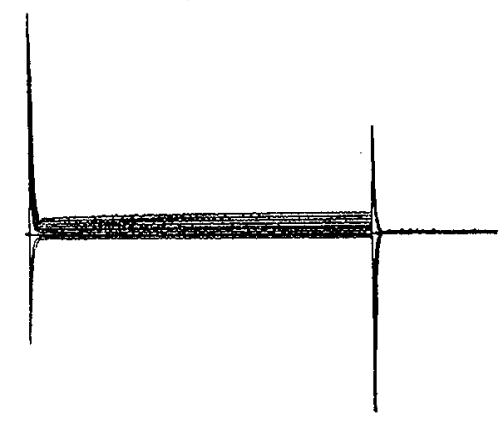

Rho1

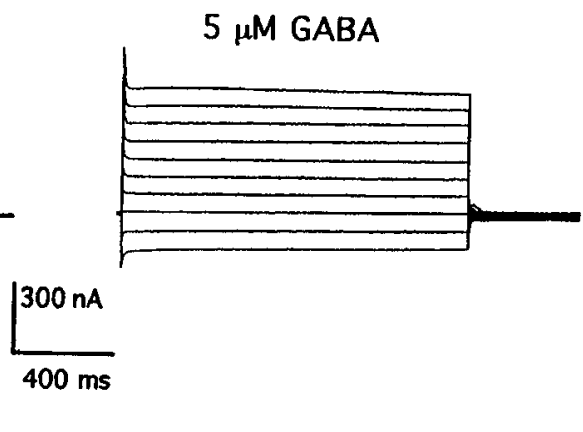

H156Y

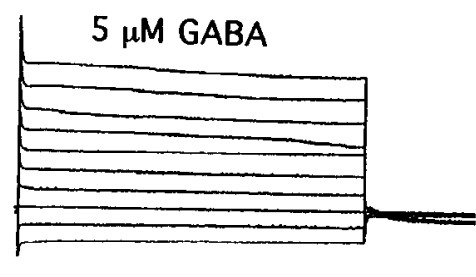

$\frac{L^{200 \mathrm{nA}}}{400 \mathrm{~ms}}$
Rho1

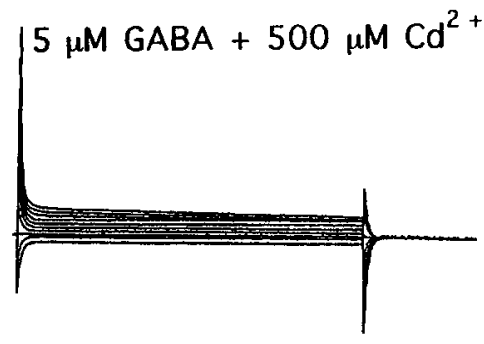

H156Y

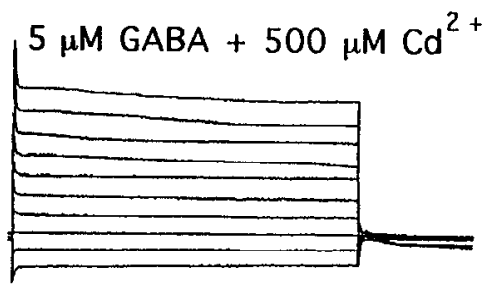

Figure 5. Continued.

the binding of $\mathrm{Zn}^{2+}$ to GABA $\rho 1$ receptors is presumed to be dynamic so that $\mathrm{Zn}^{2+}$ can quickly bind or leave this pocket. This implies that the $\mathrm{Zn}^{2+}$-binding moiety of GABA $\rho 1$ receptors might be different from the motifs associated with structural $\mathrm{Zn}^{2+}$ atoms (Vallee and Auld, 1990; Jacobs, 1995). The multimeric structure of GABA receptors further complicates the conceptualization of the molecular components of the $\mathrm{Zn}^{2+}$ binding pocket. GABA $\rho 1$ receptors, like other ligand-gated neurotransmitter receptors, are thought to be composed of five subunits. The deduced Hill coefficient of 1.5 from the $\mathrm{Zn}^{2+}$ inhibition curve (Fig. $4 B$ and Table 1 ) is consistent with cooperative binding of two (or more) $\mathrm{Zn}^{2+}$ atoms. Therefore, $\mathrm{Zn}^{2+}$ could be binding to motifs in each subunit or pockets formed by multiple subunits. Expression of $\mathrm{H} 156 \mathrm{Y}$ with $\rho 1$ does appear to alter the
$\mathrm{Zn}^{2+}$ sensitivity of $\rho \mathrm{l}$ receptors. This could be due to the formation of H156Y:pl heterooligomeric receptors with altercd $\mathrm{Zn}^{2+}$ binding properties. Alternatively, H156Y may interfere with 11 translation efficiency, receptor assembly, or trafficking to the cell membrane. Finally, $\mathrm{Zn}^{2+}$ inhibition of $\rho 1$ receptors is competitive at low concentrations $(\leq 100 \mu \mathrm{M})$ and noncompetitive at higher doses $(>100 \mu \mathrm{M})$ suggesting more than one site of $\mathrm{Zn}^{2+}$ interaction or allosteric effects between separate $\mathrm{Zn}^{2+}$ and GABA binding sites (Chang et al., 1995). The complete loss of $\mathrm{Zn}^{2+}$ sensitivity of homooligomeric $\mathrm{H} 156 \mathrm{Y}$ receptors across a wide range of $\mathrm{Zn}^{2+}$ concentrations $(0.1 \mu \mathrm{M}$ to $1 \mathrm{mM})$ is consistent with a single site of action. However, it remains possible that the H156Y mutation alters binding to multiple distinct sites by conformational changes of the multimeric receptor. Illustra-

Table 1. Comparison of several receptor properties of GABA $\rho 1$ and H156Y receptors

\begin{tabular}{llllll} 
& & & & \multicolumn{2}{l}{$\mathrm{Zn}^{2+}$ Inhibition } \\
\cline { 3 - 5 } & $\mathrm{EC}_{50}$ of GABA & $\begin{array}{l}\mathrm{IC}_{50} \text { of } \\
\text { picrotoxin }\end{array}$ & $\begin{array}{l}\text { Reversal } \\
\text { potential }\end{array}$ & $\mathrm{IC}_{50}$ & $\begin{array}{l}\text { Hill } \\
\text { coeffi- } \\
\text { cient }\end{array}$ \\
\hline p1 & $2.3 \pm 0.4 \mu \mathrm{M}$ & $28.0 \pm 5.0 \mu \mathrm{M}$ & $-20.5 \pm 2.1 \mathrm{mV}$ & $16.2 \pm 4.5 \mu \mathrm{M}$ & $1.5 \pm 0.2$ \\
$\mathrm{H} 156 \mathrm{Y}$ & $2.1 \pm 0.3 \mu \mathrm{M}$ & $34.1 \pm 7.0 \mu \mathrm{M}$ & $-21.2 \pm 2.0 \mathrm{mV}$ & $10 \mathrm{mM}^{a}$ & $\mathrm{ND}$
\end{tabular}

$\mathrm{ND}$, not determined. Data are expressed as mean $\pm \mathrm{SEM}, n=3$ for each group.

"Estimated $\mathrm{IC}_{s_{0}}$ value. 


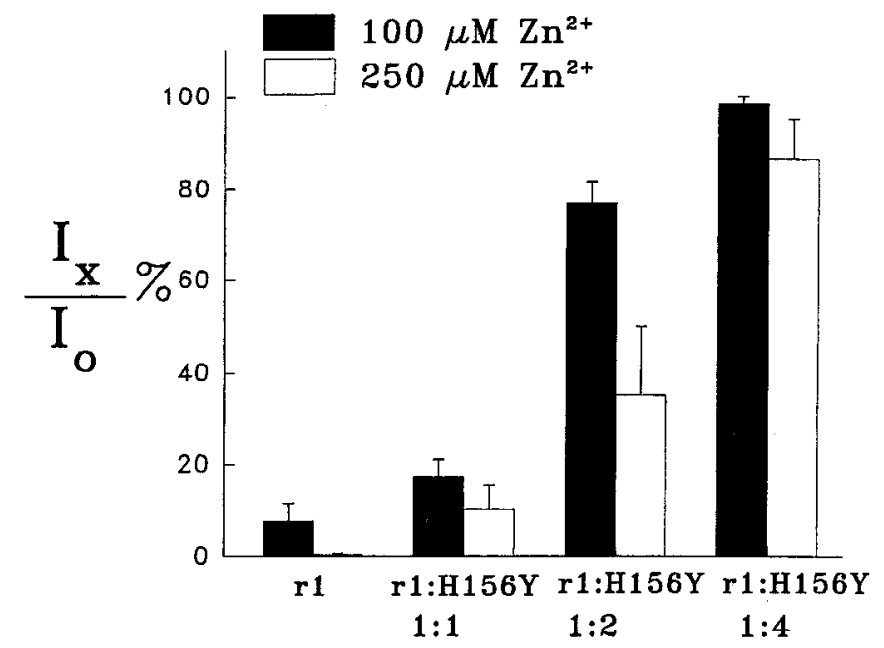

Figure 6. Coexpression of $\rho 1$ and $\mathrm{H} 156 \mathrm{Y}$ subunits. $I_{\mathrm{x}} / I_{\mathrm{O}} \%$ is the normalized response, $I_{\mathrm{O}}$ is the current response to $5 \mu \mathrm{M} \mathrm{GABA}$, and $I_{\mathrm{X}}$ is

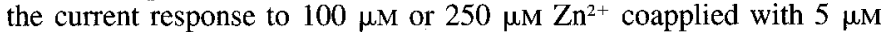
GABA. Data are expressed as mean and SEM ( $n=3$ for each group). Oocytes were injected with cither $\rho 1$ alone $(10 \mathrm{ng})$ or coinjected with three different ratios of $\rho 1$ (r1) and H156Y cRNAs. $\rho 1$ (10 ng) was mixed with the appropriate amount of H156Y cRNA to achieve the desired RNA ratios.

tion of the importance of His 156 should serve as a starting point to identify the precise molecular components of the divalent cation binding motif(s) in assembled GABA $\rho 1$ receptors.

The GABA $\rho$ subunits display 30 to $38 \%$ amino acid similarity to the $\mathrm{GABA}_{\mathrm{A}}$ suhunits and share several functional similarities including sensitivity to $\mathrm{Zn}^{2+}$ (Cutting et al., 1991; Wang et al., 1994). A number of the characteristics of the interaction between $\mathrm{Zn}^{2+}$ and vertebrate $\mathrm{GABA}_{\mathrm{A}}$ receptors resemble those elucidated here for GABA $\rho 1$ receptors. Both appear to have $\mathrm{Zn}^{2+}$ binding sites that are extracellular and distinct from the sites of action of GABA and picrotoxin (Celentano et al., 1991; Smart, 1992). Furthermore, each displays dose-dependent and voltage-independent inhibition (Westbrook and Mayer, 1987; Celentano et al., 1991; Calvo et al., 1994; Chang et al., 1995). However, there are two striking differences. Although $\mathrm{Zn}^{2+}$ inhibition of invertebrate $\mathrm{GABA}_{\mathrm{A}}$ receptors is $\mathrm{pH}$ dependent like $\rho \mathbf{l}$ receptors, similar studies of rat sympathetic neurons failed to demonstrate the same effect upon vertebrate $\mathrm{GABA}_{\mathrm{A}}$ receptors (Smart, 1992). Secondly, the potency of other divalent cations differs between $\rho 1$ and vertebrate $\mathrm{GABA}_{\mathrm{A}}$ receptors. The rank order of potency for $\rho 1$ receptors was $\mathrm{Zn}^{2+} \sim \mathrm{Ni}^{2+}>\mathrm{Cd}^{2+}$, as observed by others (Calvo et al., 1994). In studies of mature $\mathrm{GABA}_{\mathrm{A}}$ receptors in chick spinal cord neurons and rat superior cervical ganglion cells, $\mathrm{Cd}^{2+}$ has equal or greater potency than $\mathrm{Zn}^{2+}$, and $\mathrm{Ni}^{2+}$ is considerably less inhibitory than $\mathrm{Zn}^{2+}$ (Smart and Constanti, 1990; Celentano et al., 1991). Recombinant GA$\mathrm{BA}_{\mathrm{A}}$ receptors formed by $\alpha 1$ and $\beta 2$ subunits expressed in mammalian cells display a potency rank order of $\mathrm{Zn}^{2+}>\mathrm{Ni}^{2+}>$ $\mathrm{Cd}^{2+}$ (Draguhn et al., 1990). Together, these observations suggest that the amino acid composition of the $\mathrm{Zn}^{2+}$-interacting site differs between these two classes of receptors. Alignment of the $\rho$ and $\mathrm{GABA}_{\mathrm{A}}$ subunit amino acid sequences and our mutagenesis studies support this contention. The $\mathrm{GABA}_{\mathrm{A}}$ subunits"have a highly conserved asparagine in the location corresponding to the histidine conferring $\mathrm{Zn}^{2+}$ sensitivity to $\rho 1$ receptors. Substitution of this residue with asparagine resulted in a nonfunctional receptor whereas similar substitutions in $\rho 1(\mathrm{H} 274 \mathrm{~N}$ and
$\mathrm{H} 447 \mathrm{~N}$ ) were tolerated, as were substitutions at codons 78 and 120 with amino acids that are highly conserved in $\mathrm{GABA}_{\mathrm{A}}$ subunits (Fig. 3). Therefore, despite sequence and functional similarities, $\mathrm{GABA}_{\mathrm{A}}$ and $\rho 1$ receptors may have structurally diverse $\mathrm{Zn}^{2+}$ binding domains.

Numerous studies have documented that two pharmacologically distinct types of GABA receptors, $\mathrm{GABA}_{\mathrm{A}}$ and $\mathrm{GABA}_{\Gamma}$, exist in the outer retina (Polenzani et al., 1991; Feigenspan et al., 1993; Qian and Dowling, 1993, 1994; Woodward et al., 1993; Lukasiewicz et al., 1994; Lukasiewicz and Werblin, 1994). Photoreceptor cells appear to have $\mathrm{GABA}_{\mathrm{A}}$ receptors, while horizontal cells have predominantly $\mathrm{GABA}_{\mathrm{C}}$ receptors and bipolar cells have both (Djamgoz, 1995). The functional significance for the presence of two types of receptor, particularly in the same cell, is unclear. However, a wider range of responses to GABA may be a particular requirement of the first retinal synapse. Consistent with the hypothesis is the recent observation that $\mathrm{Zn}^{2+}$ acts as a neuromodulator at this synapse but has different effects on the GABA-gated currents of horizontal versus bipolar cells (Wu et al., 1993; Chappell et al., 1995; Dong and Werblin, 1995). Since GABA $\rho 1$ subunits appear to be an important constituent of $\mathrm{GABA}_{\mathrm{C}}$ receptors, the results of this study suggest a molecular basis for the diversity of $\mathrm{Zn}^{2+}$ interactions with retinal GABA receptors.

\section{References}

Akimichi K, Tachibana M (1986) Blocking effects of cobalt and related ions on the gamma-aminobutyric acid-induced current in turtle retinal cones. J Physiol (Lond) 373:463-479.

Amin J, Weiss DS (1994) Homomeric rhol GABA channels: activation properties and domains. Recept Channels 2:227-236.

Calvo DJ, Vazquez AE, Miledi R (1994) Cationic modulation of tho1 type gamma-aminobutyrate receptors expressed in Xenopus oocytes. Proc Natl Acad Sci USA 91:12725-12729.

Celentano JJ, Gyenes M, Gibbs. TT, Farb DH (1991) Negative modulation of the gamma-aminobutyric acid response by extracellular zinc. Mol Pharmacol 40:766-773.

Chang Y, Amin J, Weiss DS (1995) Zinc is a mixed antagonist of homomeric tho1 gamma-aminobutyric acid-activated channels. Mol Pharmacol 47:595-602.

Chappell RL, Qian H, Malchow RP, Ripps H (1995) Novel action of zinc on GABA receptors of skate bipolar cells. Invest Ophthalmol Vis Sci 36:S215-\#981.

Coleman JE (1992) Zinc protein: enzymes, storage, proteins, transcription factors, and replication proteins. Annu Rev Biochem 61:897946.

Cutting GR, Lu L, O'Hara BF, Kasch LM, Montrose-Rafizadeh C, Donovan DM, Shimada S, Antonarakis SE, Guggino WB, Uhl GR, Kazazian HH, Jr (1991) Cloning of the gamma-aminobutyric acid (GABA) rhol cDNA: a GABA receptor subunit highly expressed in the retina. Proc Natl Acad Sci USA 88:2673-2677.

Djamgoz MBA (1995) Diversity of GABA receptors in the vertebrate outer retina. Trends Neurosci 18:118-120.

Dong C, Werblin FS (1995) Zinc down modulates the $\mathrm{GABA}_{\mathrm{C}}$ receptor current in cone horizontal cells acutely isolated from the catfish retina. J Neurophysiol 73:916-919.

Draguhn A, Verdorn TA, Ewert M, Seeburg H, Sakmann B (1990) Functional and molecular distinction between recombinant rat GA$\mathrm{BA}_{\mathrm{A}}$ receptor subtypes by $7 \mathrm{n}^{+}$. Neuron 5:781-788.

Feigenspan A, Wassle H, Bormann J (1993) Pharmacology of GABA receptor $\mathrm{Cl}^{-}$channels in rat retinal bipolar cells. Nature 361:159161.

Harrison NL, Gibbons SJ (1994) $\mathrm{Zn}^{2+}$ : an endogenous modulator of ligand- and voltage-gated ion channels. Neuropharmacology 33:935952.

Haug F-MS (1967) Electron microscopical localization of the zinc in hippocampal mossy fibre synapses by a modified sulfide silver procedure. Histochemie 8:355-368.

Hirayama Y (1990) Histochemical localization of zinc and copper in rat ocular tissues. Acta Histochem 89:107-111. 
Jacobs GH (1995) Determination of the base recognition positions of zinc fingers from sequence analysis. EMBO J 11:4507-4517.

Legendre P, Westbrook GL (1990) Noncompetitive inhibition of gamma-aminobutyric acid channels by $\mathrm{Zn}$. Mol Pharmacol 39:267-274.

Lukasiewicz PD, Werblin FS (1994) A novel GABA receptor modulates synaptic transmission from bipolar to ganglion and amacrine cells in the tiger salamander retina. J Neurosci 14:1213-1223.

Lukasiewicz PD, Maple BR, Werblin FS (1994) A novel GABA receptor on bipolar cell terminals in the tiger salamander retina. J Neurosci $14: 1202-1212$.

Polenzani L, Woodward RM, Miledi R (1991) Expression of mammalian gamma-aminobutyric acid receptors with distinct pharmacology in Xenopus oocytes. Proc Natl Acad Sci USA 88:4318-4322.

Qian H, Dowling JE (1993) A novel GABA response from rod-driven horizontal cells of the white perch retina. Nature 361:162-164.

Qian H, Dowling JE (1994) Pharmacology of novel GABA receptors found on rod horizontal cells of the white perch retina. J Neurosci 14:4299-4307.

Saxena NC, Macdonald RL (1994) Assembly of GABA receptor subunits: role of the $\delta$ subunit. J Neurosci 14:7077-7086.

Shimada S, Cutting GR, Uhl GR (1992) GABA A or C receptor?: GABA rho1 receptor RNA induces bicuculline, barbiturate and benzodiazepine-insensitive GABA responses in Xenopus oocytes. Mol Pharmacol 41:683-687.

Smart TG (1992) A novel modulatory binding site for zinc on the $\mathrm{GABA}_{\mathrm{A}}$ receptor complex in cultured rat neurones. J Physiol (Lond) 447:587-625.
Smart TG, Constanti A (1982) A novel effect of zinc on the lobster muscle GABA receptor. Proc R Soc Lond [Biol] 215:327-341.

Smart TG, Constanti A (1990) Differential effect of zinc on the ver-

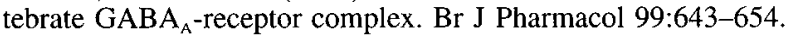

Smart TG, Moss SJ, Xie X, Huganir RL (1991) GABA $_{A}$ receptors are differentially sensitive to rinc: dependence on subunit composition. Br J Pharmacol 103:1837-1839.

Vallee BL, Auld DS (1990) Zinc coordination, function, and structure of zinc enzymes and other proteins. Biochemistry 29:5647 5659.

Wang T-L, Guggino WB, Cutting GR (1994) A novel gamma-aminobutyric acid receptor subunit (rho2) cloned from human retina forms bicuculline-insensitive homooligomeric receptors in Xenopus oocytes. J Neurosci 14:6524-6531.

Westbrook GL, Mayer ML (1987) Micromolar concentrations of $\mathrm{Zn}^{2+}$ antagonize NMDA and GABA responses of hippocampal neurons. Nature 328:640-643

White G, Gurley DA (1995) $\alpha$ Subunits influence $\mathrm{Zn}^{2+}$ block of gamma2 containing GABA ${ }_{\mathrm{A}}$ receptor currents. Neuroreport 6:461-464.

Woodward RW, Polenzani L, Miledi R (1993) Characterization of bicuculline/baclofen-insensitive (rho-like) gamma-aminobutyric acid receptors expressed in Xenopus oocytes. II. Pharmacology of gamma-

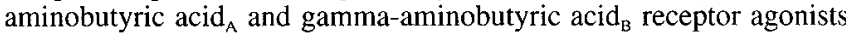
and antagonists. Mol Pharmacol 43:609 625.

Wu SM, Qiao X, Noebels JL, Yang XL (1993) Localization and modulatory actions of zinc in vertebrate retina. Vision Res 33:2611-2616.

Yon J, Fried M (1989) Precise gene fusion by PCR. Nucleic Acids Res 17:4895 